\title{
A COMPARATIVE STUDY ON HEALTHY AND CLEAN LIFESTYLE (PHBS) IN ELEMENTARY SCHOOL BASED ON GEOGRAPHICAL LOCATION
}

\author{
Yudha Febrianta ${ }^{1}$, Sriyanto ${ }^{2}$, Pratik Hari Yuwono ${ }^{3}$ \\ yudhafebrianta@ump.ac.id, sriyanto@ump.ac.id, pratikhariyuwono@ump.ac.id \\ ${ }^{123}$ Universitas Muhammadiyah Purwokerto, INDONESIA
}

Received 25 January 2021 - Revised 22 Februari 2021 - Accepted 22 March 2021

\begin{abstract}
Theoretically this research was based on that health which affect cleanliness appriciate behavior. This research aiming to find out the difference of healthy and clean lifestyle for elemantary school student based on geographical location between highland and lowland. Proportionate stratified random sampling was used to decide the sample. Questionnaire was used toward 184 respondent to collect the data. Independent t- test with assist from SPSS $\vee 23$. 0 Software were used to analized collected data. The result of this research are; there is a significant differences of healthy and clean lifestyle pattern between elementary school in sub-district Baturraden Banyumas with subdistcrict petanahan Kebumen. The conclusion from the research is, student from highland applied more clean lifestyle pattern than lowland student.

Keywords: clean lifestyle, health, environment characteristic, students.
\end{abstract}

\section{INTRODUCTION}

Healthy condition is the will of all parties, not only dominated by individuals, but must also be owned by the group and even by the community. In the RI Health Law No.36 of 2009, "Health is a state of being healthy, good physically, mentally, spiritually and socially which allows everyone to live socially and economically productive". This means that health in a person or the individual includes physical, mental, spiritual and social aspects in order to achieve it a prosperous condition for someone both with their productivity and also their economy.

Health status is influenced by 4 factors, namely factors environment, behavioral factors, heredity and health service factors. Of the four these factors, the second factor, namely behavior factors are very influential in health a person, especially in implementing PHBS (Clean and Healthy Lifestyle) is good in the personal, family, and community environment [1].

Clean and healthy living behavior (PHBS) is a step that must be taken to achieve the optimal degree of health for everyone. Health conditions are not as well it immediately happens, but it must always be strived from being unhealthy to being alive healthy and create a healthy environment. This effort must start from instilling a healthy mindset towards society that must be started and worked on by oneself. This effort is to realize the highest public health status as an investment for productive human resource development. In striving for this behavior requires a mutual commitment to support each other in increase the health status of the community, especially the family so that development maximum health can be achieved

Clean and healthy lifestyle coaching in the school level, hold through Health School Unit Program (UKS). The program was lead by teacher associate with the nearest health center to support PHBS activity maximally. Republic of indonesian Health ministry describe the role of UKS in PHBS coaching that is to arrange the plan, holding, monitoring, and evaluating PBHS coaching. those thing were inline with the School health unit three pilar (trias UKS) including Health Education, Health service,and school health environment maintenance. School Health Unit program as PHBS coach for maximize health and clean lifestyle pattern for school community especially student. In this context the school in question is an elementary school under the Education System Law National Number 20 of 2003 Article 17 is stated to be the level of education that underlies the level of education medium. Based on this law, the role of elementary schools is very important and strategic as education formal accepted by students to

(C) 2021 by the authors; licensee PGSD UMP. This article is an open access article distributed under the terms and conditions of the Creative Commons Attribution License (http://creativecommons.org/licenses/by/4.0/). 
underlie further education, namely Junior High School (SMP) and affect the next level of education [2].

Until now the behavior is alive healthy is a special concern especially for the government. This is because PHBS is used as a benchmark in threats to increase coverage health in the Sustainable program Development Goals (SDGs) 2015-2030. PHBS in the SDGs is wrong one form of revention have a short term impact on in health improvement at three place, among others, within the scope of members family, the general public, as well schools [3].

PHBS program is a form of realisation to give study experience or create a conducive situation for individual, group, and society to create knowledge, behavior and attitude so that they will be able to applied the way of healty life in order to keep, maintain, and elevate the health [4]. Clean and healthy lifestyle (PHBS) for elementary student begin with clean lifestyle behavior practice inside and outside the class, such as the proper brushing habbit, washing hand, and also cleaning nail and hair [5]. PHBS application can be done thorugh School Health Unit (UKS) approach [6].

There are still many discrepancy in application of clean and health lifestyle (PHBS) on Indonesian. Many disease can be found inside the body if someone neglect to wah their hand, such as typhus, fungus infection, polio, dysentry, diarrhea, cholera, worms infection, Upper Respiratory Tract Infection (URI) and Hepatitis A[7]. Clean and healthy lifestyle in society is one of the important factor to support the resident health factor enhancement. School become an important place in order prevention and promoting healthy lifestyle, giving education information so it can increase the education, attitude, and behavior [8].

Report from Riset Kesehatan Dasar/ Riskesda Nasional 2013: stated that health is affected by cleanliness apresiation behavior. There were still many health problem experinced by elementary student such as $86 \%$ of tooth problem, 53\% can't cut their nail, 43\% can't properlly brush their tooth, and 8\% didn't wash their hand before eat. Based on the majority diseasse suffered by elementary school student $60 \%-80 \%$ were got worm infection and $74,4 \%$ got tooth carries[9]. Comprehensiffe effort are needed in many factor to solve those problem. Behavior disorder, health infection, digestive tract disease, respiratory tract disesase, skin disease and malnutrition are the common health problem that occur in school age children [10]. The fact on the field still shown that there is stil high precentage of elementary school didn't know about PHBS either individual or environment.

Clean and health elementary school/Sekolah Dasar Bersih Sehat (SDBS) is an elementary school which all of their member continously develop PHBS and has clean, beautiful, cold, fresh, neat, orderly, and safe school environment. Clean and healthy lifestyle/Pola Hidup Bersih dan Sehat (PHBS) can be start from family environment, since family has important role to prevent infectious and non infectious disease. Sinergi between shool and family in create environmnet and clean healthy lifestyle become a support system to increase better lifestyle [11]. Is beginning to held PHBS.

Based on that riset, intensive knowledge and PHBS activity which done inside or outside the school will become important role for students life. The closest people such as, teacher and parents should support students effort to maintain their health and their cleanliness. That thing inline with the riset result done in PHBS scope. From the result of a riset done by Emi Listiyani about the comparasion level of student knowledge about healthy behavior between civil elementary school and private elementary school, it is found that the success in health education not only decided by the support of member of the school and parents, instead the connection between parents and teacher which make it succes. The knowledge that given by teacher in school should be supported by the parents at home.

PBHS coaching were done differently depend on each region, this phenomenont make PBHS coaching has its own advantages and disadvantages in the implemeentation. Sometimes the coaching adjusted depend on the geographical environment factor, local culture, local believes, also supported with facillity and infrastructure for PBHS.

This research was done in two school namely, Kemutug lor 1 elementary school and Munggu elementary school. Both school are already applied PBHS coaching, teachers from both school assume that PBHS activity give possitive impact toward study process, especially in term of convinience and good study achievement. During the process, headmaster always give direction to the teacher, student, and school janitor to always optimilize PHBS Coaching.

Booth school also work with local health service such as health center and doctor to support PHBS coaching. teacher from booth school also explain, with PHBS coaching in school will reduce the precentage of absnet student due to health reason. Fever, maag, tootcahe, cough,and flu are some of the symptoms which offen experienced by students. In order to realize students ideal health, booth school continue to maximize PBHS coaching and also work together students parent.

The location of booths school are drasticlly different, kemutug lor 1 elementary school was located in kemutug lor village in sub district Baturraden in Banyumas regency, which located in hihghland. The air temperature were low and cold also the humidity was high. Other school Munggu elementary school were loacted in Munggu vilage sub distrtict petanahan in Kebumen regency, which located in lowland near local beach. The local physical environment condition in munggu was hot and sandy.

The differencess in booth local physical environment, make two school has its advantages and disadvantages in PBHS coaching. based on those conditions, writers are were intersted to make article entitled "Study Komparasi Perilaku Hidup Bersih dan Sehat (PBHS) in Elementary School base on Geographical Location". 


\section{MATERIAL AND METHODS}

Method used in this research was comparative research and through quantitative approach. This research aim to found out wether there was any different in applied the clean and health lifestyle (PBHS) on high class in Kemutug Lor 1 elementary school with the Munggu elementary school which has different physical environmnent characteristic. Kemutug Lor civil elementary school is a school that located in highland, meanwhile Munggu elementary school is a school that located in lowland. Grade 4,5,6 elementary student from booth school were choosen as the population in this research,total population in this research was 239 students. Sample in this resesarch was taken trough proportionate stratified random sampling with Taro Yamane formula. There were 184 total sample, 86 students came from Kemutug lor 1 elementary school and 98 students were came from Munggu elementary school.

\section{RESULTS AND DISCUSSION}

Based on the callculation test of independent-sampel t test using SPSS Ver 23.0 produce sig value. (2-tiled) 0,000. Sig value. (2-tiled) 0,000 < 0,05 so H9 rejected and $\mathrm{H} 1$ accepted, which mean there were differences between Kemutug lor 1 elementary school PHBS and Munggu elementary school PHBS, there were differences between PHBS in Elementary school which has different geographical location.

Table 1. Calculation result of SPSS Independetent-Sample T Test

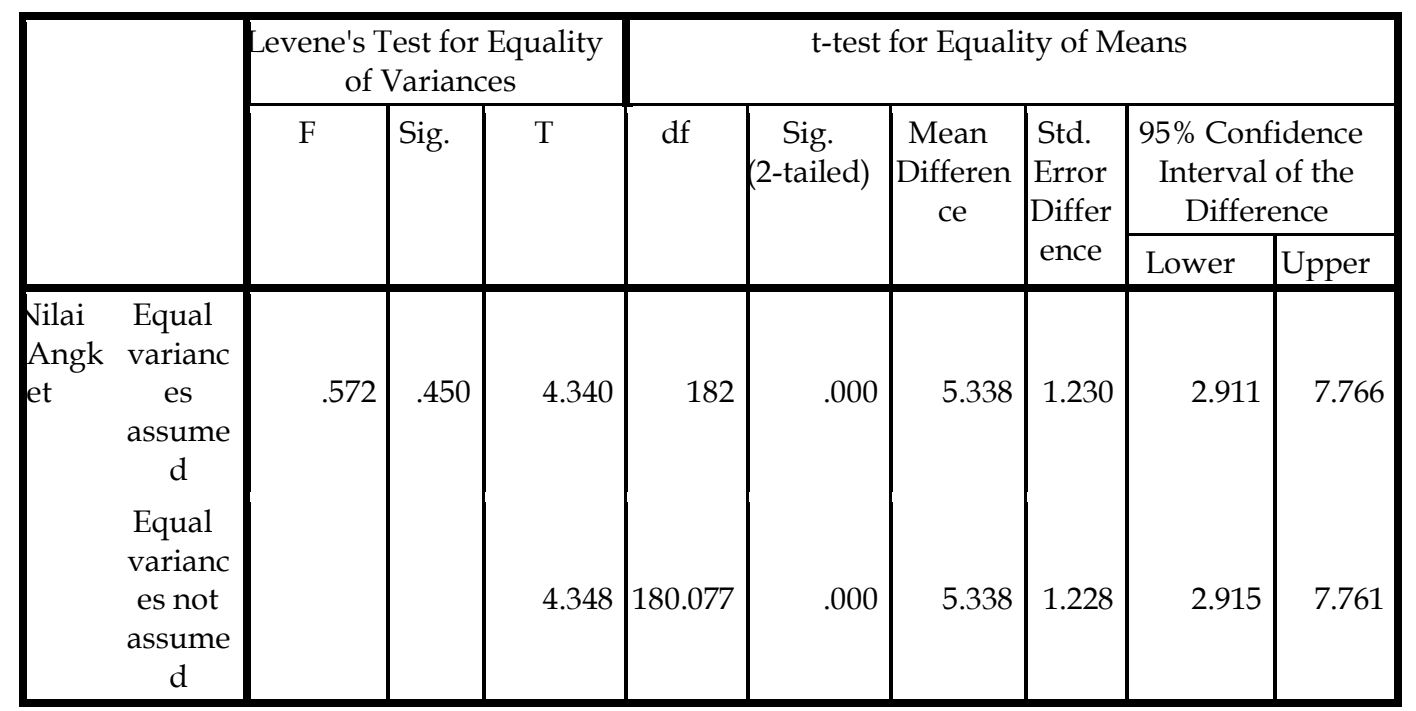

Result of independent-samples t test with equal variances variances assumed, for hipotesis $H_{0}: \mu_{1}=\mu_{2}$ toward $H_{1}: \mu_{1} \neq \mu_{2}$ which give $\mathrm{t}$ value $=4,340$ with freedom level $=182$ and $P$ - value $(2$-tailed $)=0,000$, because $P$-Value ( 2 tailed) $=0,000$ smaller than $\alpha=0,05$ so $H_{0}: \mu_{1}=\mu_{2}$ was rejected. Questionaire Mean of Kemutug lor 1 elementary school was different with questionaire value of Munggu elementary school, or it was can be said there were differences of PBHS in high grade class from Kemutug lor 1 elementary school and PBHS in Munggu elementary school. Interpretation result with questionaire would be supported with observation result to found out about the cause of difference indepthly.

There were six aspect used in the questionaire. The aspects are; individual cleanlines aspect, environment cleanlines aspect, diet aspect, break pattern aspect, phisical activity and sport pattern aspect, disease prevention and handling pattern aspect in booth school, it was found that "High" PHBS in high grade class of kemutug lor 1 elementary school were done by 15 students or $17.44 \%$. Enough" PBHS were done by 56 students or $65.12 \%$. and for "less" PBHS there were done by 15 students or $17.44 \%$. Meanwhile in High grade class of Munggu elementary school it were found that "High" PBHS were done by 17 students or 17.35\%. "Enough" PBHS were done by 64 students or $65.30 \%$ and for "less" PBHS were done by 17 students or $17.35 \%$

\section{DISCUSSION}

Based on the research result there were differences form students PBHS knowledge. Teachers and health personel in school already tied to give the basic of PHBS indicator to each student in school [12]. Teacher as an educator should be able to change students attitude into the one that has responsiblelity toward their on health [13]. PHBS promotion need to start in early ages, so that could be an extra knowledge for student so they will be able to applied it in their daily life, and also will become their life norm [14]. School ages was the gold phase to give students 
the value of PBHS and there would be a chance for them to become agent of change to promote PHBS in school environmnet, family, and society [15].. School is an education institution which become PBHS target, so the applied of those attitude will become more effective [9]. The succes in held Health unit for student in school are depend on the management proccess developed by school, from the planning, organizing, implementing or movement, and controling School Unit activity continously [16]. School was expected to be able to applied the healthy lifestyle as on of the facilitation to increase the knowledge and skill of school member in healthy lifestyle [17]. Clean and healty lifestyle program (PBHS) is realization to give study experience [4]. Student also will be able to gain PBHS in society, clean and healhty lifestyle are a set of attitude which applied based on the realization of study result which make someone, family, group, or society be able to help their self in medical field and actively act to realize Health of society [18]. Factors that determine behavior health in individuals one of them namely the level of knowledge. Knowledge itself is the basis of one's deep implement actions, so that everyone who will practice actions usually begin with the ability to know, next have an idea to do a action based on his knowledge which he had [19].

Many factor affected clean and healthy lifestyle, such as someone behavior in their house, society environment, school, teacher which not giving the good example to the children itself [20]. PHBS is needed to increase the health level in society [21]. Elementary school period is a gold period to teach the value of PBHS[22]. Local Health Center are suppodsed to give knowledge about the proper clean and healthy lifestyle[23]. The disease appearance that infect school grade (6-10 years old) commonly related with PBHS[24].

Some other factors that cause the differences :

1. School geographical location
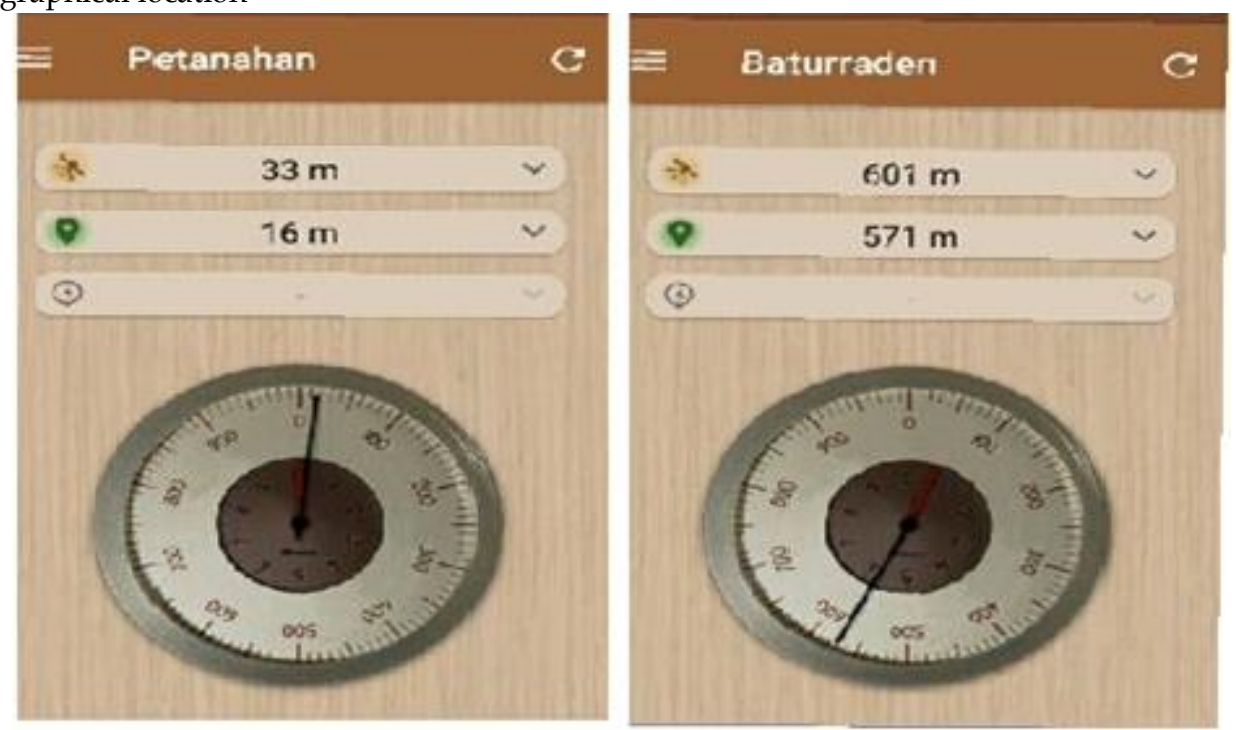

Kemutug lor 1 elementary school and Munggu elementary school were two school with different environment characteristic. Based on the geographical location of Kemutug lor 1 elementary school which located in sub-district Baturraden in Bnyumas region, the location can be categorized located in highland, based on the scalling by using altimeter it is found out the school located in 610-700 meter above sea surface. That explained that highland is an land surface which located 400 meter above the sea surface[25]. Kemutug lor 1 elementary school can be categorized located in highland becuase the school located in 571 above the sea surface.

Geographical location has its advantages and disadvantages, the problem that appear in kemutug lor village is the water easilly become muddy when heavy rain come, people were start to resolve this problem litle by litle, on of the example was in kemutug lor 1 elementary school which always filtering the water before being used by the school member, janitor also always watch the clearlines of the water. Trash and sandy road were the problem found in munggu elementary school, people around the school and also the school member always clean the environment around the school. The janitor always showrering the school yard with the water so that when the wind come the dusk won't blown easily.

There is no differences in PHBS coaching in different geographical environment, it could be happen because people were able to maximize their local potential in order solve the problem in their environment especially in support PHBS coaching, and always stay with the PHBS indicator. The differnce in PHBS coaching in different geographical environment would be reduced if people were able to keep up with PHBS Indicator in act or knowledge and also not foget to maintain their environment.

2. Parents Education and Economic Factor

Student's parents Education and economic factor would be effecting the PHBS coaching in home. One of the important factor wether or not PHBS coaching will be succes is parent. Most of the student's parents from kemutug lor 1 elementary school only finishied their educational stage in elementary school. Most of the father work as Hotel Staff, labor, and most of the mother work as housewife. 
Febrianta, els / clean lifestyle, health, environment characteristic, students.

Majority of the student's father in munggu elementary school finished their educational stage in elementary school, meanwhile majority of the mother finished the educational stage in junior high school. Most of the father work as farmer, and trader, meanwhile the mothers work as housewife. Educational status, job, and family economic condition would effect the PHBS coaching wether knowledge and practical.

3. Health strata of the two school.

Local health center was used as the instrument to observe school health strata, the instrument was developed through school PHBS indicator. Below are the indicator school health strata criteria :

\begin{tabular}{|l|l|}
\hline SEHAT PRATAMA (RED) & The indicator value shown result between 1until 6 \\
\hline SEHAT MADYA (YELLOW) & The indicator value shown result between 7 until 11 \\
\hline SEHAT UTAMA (GREEN) & The indicator value shown result between 12 until 14 \\
\hline SEHAT PARIPURNA BLUE) & The indicator value shown result 15 \\
\hline
\end{tabular}

PHBS observation result in Kemutug Lor 1 elementary school got 14 value. PHBS in Kemutug lor 1 elementary school categorized in "SEHAT UTAMA" school which represent in green. PHBS observation result in Munggu elementary school got 10 value. PHBS in Munggu elementary school categorized in "SEHAT MADYA" which represent in yellow.

\section{CONCLUSION}

There is no differences in PHBS coaching in different geographical environment, it could be happen because people were able to maximize their local potential in order solve the problem in their environment especially in support PHBS coaching, and always stay with the PHBS indicator. The differnce in PHBS coaching in different geographical environment would be reduced if people were able to keep up with PHBS Indicator in act or knowledge and also not foget to maintain their environment

Majority of the student's father in munggu elementary school finished their educational stage in elementary school, meanwhile majority of the mother finished the educational stage in junior high school. Most of the father work as farmer, and trader, meanwhile the mothers work as housewife. Educational status, job, and family economic condition would effect the PHBS coaching wether knowledge and practical.

PHBS observation result in Kemutug Lor 1 elementary school got 14 value. PHBS in Kemutug lor 1 elementary school categorized in "SEHAT UTAMA". PHBS observation result in Munggu elementary school got 10 value. PHBS in Munggu elementary school categorized in "SEHAT MADYA".

\section{REFERENCES}

[1] Bloom, Benyamin S. 1974. Taxonomy of Educational Objectives. David McKay Company, New York. Hal. 22.

[2] Sonhadji, A. 2014. Manusia, Teknologi, dan Pendidikan Menuju Peradaban Baru. Malang. Universitas Negeri Malang.

[3] Kemenkes RI .2015. Profil Kesehatan Indonesia.

[4] Husni Abdul Gani. 2015. Perilaku Hidup Bersih Dan Sehat (PHBS) Pada Tatanan Rumah Tangga Masyarakat Using (Studi Kualitatif di Desa Kemiren, Kecamatan Glagah, Kabupaten Banyuwangi). Jurnal IKESMA Volume 11 Nomor 1 Maret 2015.

[5] Amalia, F., S.A. Nugraheni, A. Kartini. 2018. Pengaruh Edukasi Gizi Terhadap Pengetahuan Praktik Calon Ibu Dalam Pencegahan Kekurangan Energi Kronik Ibu Hamil (Studi Pada Pengantin Baru Wanita di Wilayah Kerja Puskesmas Duren, Semarang). Jurnal Kesehatan Masyarakat Vol. 6: 370-377.

[6] Tanjung, Nelson. 2016. Efektifitas Berbagai Bentuk Fly Trap Dan Umpan Dalam Pengendalian Kepadatan Lalat Pada Pembuangan Sampah Jalan Budi Luhur Medan. Jurnal Kesmas. Poltekkes. Medan.

[7] Pauzan. 2017. Hubungan Pengetahuan dengan Perilaku Cuci 65 Tangan Siswa di Sekolah Dasar Negeri Kota Bandung. Jurnal Keperawatan Vol.5. No.1.

[8] Prabowo. (2016), Dokumentasi Asuhan Keperawatan, 1-yogyakarta. Pustaka Baru Press

[9] Henico Putri Lina. 2016. Perilaku Hidup Bersih Dan Sehat (PHBS) Siswa Di SDN 42 Korong Gadang Kecamatan Kuranji Padang. Jurnal Promkes, Vol. 4, No. 1 Juli 2016: 92-103.

[10] Intan Kumalasari. 2017. Kesehatan Reproduksi Untuk Mahasiswa Kebidanan dan Keperawatan. Jakarta: Salemba Medika. 
[11] Rompas, S. 2018. Hubungan Fungsi Keluarga dengan Kualitas Hidup lanjut Usia di Wilayah Kerja Puskesmas Ranomuut Kecamatan Paal II Kota Manado.

[12] Linda Suryani (2018). Gambaran Menyikat Gigi Terhadap Tingkat Kebersihan Gigi Dan Mulut Pada Murid Kelas V Di MIN 9 Kecamatan Ulee Kareng Kota Banda Aceh. Jurnal Ilmiah Biologi Teknologi dan Kependidikan. , ISSN: 2337-9812, Vol. 5, No. 2, Ed. September 2017, Hal. 149-156.

[13] Indah Prasetya Tri Purnama Sari. 2013. Pendidikan kesehatan sekolah sebagai proses perubahan perilaku siswa. Jurnal Pendidikan Jasmani Indonesia. Volume 9, Nomor 2, November 2013. Jurusan Pendidikan Olahraga FIK UNY.

[14] O. Janis, Cyndhanita, dkk. Gambaran Perilaku Hidup Bersih Dan Sehat (Phbs) Pada Siswa Sekolah Dasar Negeri 30 Manado, Fakultas Kesehatan Masyarakat Universitas Sam Ratulangi.

[15] Hendrikus NK. 2016. Faktor risiko yang mempengaruhi kadar gula darah puasa pada pengguna layanan laboratorium. Jurnal Ilmiah Ilmu Kesehatan.

[16] Anna Susana .2018. Manajemen Kesehatan Peserta Didik Sekolah Dasar. Jurnal Administrasi Pendidikan Vol.XXV No.1 April 2018. Universitas Pendidikan Indonesia.

[17] Iswandi. 2016. Peran Sekolah Dalam Menumbuhkembangkan Perilaku Hidup Sehat Pada Siswa Sekolah Dasar (Studi Multi Situs Di SD Negeri 6 Mataram Dan SD Negeri 41 Mataram Kota Mataram Nusa Tenggara Barat). Volume: 1 Nomor: 3 Bulan Maret Tahun 2016 Halaman: 492 -498. Jurnal Pendidikan.

[18] Gita Sekat. 2018. Faktor-Faktor yang mempengaruhi tingkat Perilaku Hidup Bersih Dan Sehat Pada Tatanan Rumah Tangga Di Wilayah Kerja Puskesmas Poned X. Jurnal Ilmu Kesehatan dan Dokter Keluarga. Vol. 14 No. 1 (2018): Juni 2018

[19] Notoatmodjo, S. 2012. Promosi Kesehatan dan Perilaku Kesehtan. Jakarta: PT

[20] Rineka Cipta.

[21] Ratna Julianti. 2018. Pelaksanaan Perilaku Hidup Bersih Dan Sehat (PHBS) Di Lingkungan Sekolah. Jurnal Ilmiah Potensia, 2018, Vol 3. (1), 11-17.

[22] Layya., Imran., Nasaruddin. (2016) Perilaku Hidup Bersih Dan Sehat (Phbs) Dalam Tatanan Rumah Tangga Berbasis Kerusakan Akibat Tsunami Di Wilayah Kota Banda Aceh. Jurnal Ilmu Kebencanaan (Jika), 3 (1) : 21.

[23] Fivi Melva Diana. 2013. Omega 6. Jurnal Kesehatan Masyarakat, September 2012-Maret 2013, Vol. 7, No. 1

[24] Hilda Irianty. 2018. Hubungan Perilaku Hidup Bersih dan Sehat (PHBS) dengan kejadian diare pada balita. Jurnal Kesehatan Masyarakat Vol 8, No 1 (2018).

[25] Aswadi dkk, 2018. Perilaku Hidup Bersih Dan Sehat (Phbs) Pada Siswa-Siswi Sdk Rita Pada Kecamatan Kota Komba Kabupaten Manggarai Timur Propinsi Nusa Tenggara Timur. Volume 9, (2), hal 187

[26] Husein Umar. 2013. Metode Penelitian untuk Skripsi dan Tesis. Jakarta: Rajawali

\section{http://jurnalnasional.ump/index.php/dinamika}

